\title{
Peningkatan Produktivitas Usaha Budidaya Ayam Kampung UKM Putra Budi Kecamatan Mojolaban Kabupaten Sukoharjo
}

\author{
Rendi Fathoni Hadi, Wara Pratitis Sabar Suprayogi, Eka Handayanta, Sudiyono, Aqni \\ Hanifa, Susi Dwi Widyawati
}

\author{
Program Studi Peternakan, Universitas Sebelas Maret, Surakarta, Jawa Tengah \\ *Corresponding Author: rendi_fathoni@staff.uns.ac.id \\ Dikirim: 03-10-2020; Diterima: 29-07-2021
}

\begin{abstract}
ABSTRAK
Usaha Kecil Menengah (UKM) Putra Budi yang berlokasi di Desa Bekonang, Kecamatan Mojolaban, Kabupaten Sukoharjo merupakan unit usaha milik Bapak Apri. UKM Putra Budi bergerak pada usaha peternakan ayam kampung secara tradisional dengan kapasitas 50-100 ekor/periode. Bapak Apri memulai usaha ini sejak 5 tahun yang lalu, metode pemeliharaan masih sederhana sehingga produktivitasnya rendah. Penjualan ayam dilakukan dengan sistem borongan atau tanpa melihat bobot badan keseluruhan yang menyebabkan harga menjadi lebih murah. Pemberian pakan juga belum memenuhi standar kebutuhan ternak. Masalah utama yang dihadapi pada UKM Putra Budi terletak pada manajemen pemeliharaan ayam kampung yang meliputi manajemen pakan, kandang, sanitasi, pemilihan bibit indukan, dan penetasan yang dilakukan secara tradisional (ekstensif). Kegiatan ini bertujuan untuk meningkatkan usaha budidaya ayam kampung dengan menerapkan usaha budidaya yang intensif, diversifikasi pola pemasaran ayam kampung, serta mampu meningkatkan pendapatan mitra. Beberapa solusi yang ditawarkan adalah memberikan pengetahuan tentang manajemen pemeliharaan ayam kampung dengan manajemen intensif yang terprogram. Hasil dari kegiatan ini adalah UKM dapat mengaplikasikan manajemen pakan dengan pemilihan bahan baku pakan yang ada di sekitar lokasi dan praktik penyusunan ransum ayam kampung yang berkualitas, sistem pemeliharaan ayam kampung tipe pedaging yang terbebas dari penyakit/virus yang berbahaya, peningkatan produktivitas, efisiensi dan kecepatan balik modal, serta dapat menjalin kerjasama dengan rumah makan atau UKM pengolahan ayam kampung. Berdasarkan analisis ekonomi yang dilakukan, pemeliharaan ayam kampung UKM Putra Budi dengan 200 ekor mengalami deplesi 5\% dan memperoleh keuntungan sebesar Rp1.400.000,00 per periode pemeliharaaan.
\end{abstract}

Kata kunci: ayam kampung, manajemen pakan, pemeliharaan intensif, peningkatan pendapatan

\section{Increasing the Productivity of Kampong Chicken in the Putra Budi SME's Mojolaban District Sukoharjo Regency}

\section{ABSTRACT}

Putra Budi Small and Medium-Sized Enterprises (SMEs) located in Bekonang Village, Mojolaban Subdistrict, Sukoharjo Regency, is a business unit owned by Mr Apri with traditional kampong chicken breeding with a capacity of 50-100 chickens/period. Mr Apri. Putra Budi SMEs is engaged in traditional village chicken farming with a capacity of 50-100 chickens/period. Mr Apri started this business 5 years ago, but the maintenance method is still simple and has not been carried out intensively so that the productivity is low. Chicken sales are carried out on a wholesale basis, causing lower prices. Providing feed that does not meet the standard needs of livestock. The main problem faced by Putra Budi SME's lies in the management of native chicken maintenance which includes management of feed, cages, sanitation, selection of broodstock, and hatching which are carried out traditionally (extensively). This service aims to increase the business of native chicken cultivation by implementing intensive cultivation, diversifying the marketing pattern of native chickens, and being able to increase partner income. Some of the solutions offered are to provide broader knowledge about the management of domestic chicken rearing which is still extensive/traditional towards programmed intensive management. The result of this service activity is that SME's can apply feed management by selecting feed raw materials around the location and the practice of compiling quality native chicken rations, broiler-type chicken maintenance systems that are free from dangerous diseases/viruses, increasing productivity, efficiency, and speed of return on investment, and can establish cooperation with restaurants or SMEs processing native chicken. Based on the economic analysis carried out, the maintenance of the Putra Budi village chickens with 200 chickens experienced a 5\% depletion and earned a profit of IDR 1,400,000 per breeding period.

Keywords: intensive maintenance, increased income, kampong chicken, SME's 


\section{PENDAHULUAN}

Pola peningkatan pemberdayaan masyarakat yang produktif dan sesuai dengan kebutuhan masyarakat dapat dilakukan dengan beberapa cara seperti pemberian pelatihan teknis, pendampingan mitra usaha produktif, dan pembinaan secara masif terhadap masyarakat di bidang usaha yang produktif dan nyata. Bidang usaha yang potensial dalam meningkatkan pendapatan bagi masyarakat antara lain pertanian/bercocok tanam (Dewi et al., 2017), peternakan (Muhtar et al., 2020; Suresti \& Wati, 2012), dan industri kecil (UKM) (Permana, 2017). Di bidang peternakan khususnya ayam kampung, pemerintah mengeluarkan regulasi untuk memproteksi ayam lokal melalui Peraturan pemerintah (Perpres) No. 44 (2016) tentang Daftar Bidang Usaha yang Tertutup dan Bidang Usaha yang Terbuka dengan Persyaratan di Bidang Penanaman Modal yang menjelaskan bahwa pelaku usaha ternak ayam kampung dibatasi hanya untuk beberapa sistem usaha mikro, kecil, menengah, dan koperasi (UMKM). Peraturan ini membuka serta mendorong peluang usaha peternakan ayam kampung bagi peternak rakyat (Pratitis et al., 2018).

Ayam lokal atau yang lebih dikenal dengan ayam kampung merupakan plasma nutfah ternak unggas asli Indonesia yang potensial (Suprayogi et al., 2018) dan memiliki kemampuan adaptasi yang tinggi terhadap lingkungan (Nangoy \& Karisoh, 2018) sehingga cocok untuk dikembangkan oleh masyarakat kecil dan menengah. Potensi usaha peternakan juga dapat dilihat dari jumlah permintaan protein hewani asal unggas oleh masyarakat yang sadar akan pentingnya protein hewani dengan nilai gizi tinggi dan aman untuk dikonsumsi (Suprayogi et al., 2018). Rata-rata konsumsi daging ayam kampung penduduk Indonesia adalah 5,8 g/kapita/hari, sehingga jumlah asupan protein hewani dapat terpenuhi dari komoditas peternakan dari ternak ayam lokal (Munir et al., 2016). Ayam kampung cocok diternakkan oleh masyarakat Indonesia sebagai salah satu komoditas protein hewani yang murah dan mudah didapatkan. Jumlah konsumsi daging ayam kampung/ras pada tahun 2019 sebesar 12,4 g/kapita/minggu (BPS, 2020). Bergesernya minat konsumsi daging ayam broiler ke ayam kampung saat ini cukup besar karena cita rasa dari daging ayam kampung lebih disukai, selain itu peluang di pasar juga masih terbuka lebar.
Pola pemeliharaan ayam kampung yang banyak dilakukan oleh peternak di pedesaan adalah pola pemeliharaan yang sederhana/ekstensif. Pola ekstensif merupakan pola pemeliharaan ayam kampung yang membiarkan ayam bebas berkeliaran dan mencari makanan sendiri (Tarigan et al., 2021) tanpa diukur berapa kebutuhan yang sesuai. Bahan pakan yang biasa diberikan untuk ayam kampung dengan pola ekstensif yaitu nasi sisa, nasi kering/aking, dan sisa makanan manusia. Pola ini memiliki beberapa kelemahan yaitu berdasarkan sisi keuntungan yang diperoleh masih belum optimal, sedangkan dari sisi kualitas dan kuantitas nutrisi dalam pakan serta jumlah ayam yang dipelihara masih sedikit, sehingga menjadikan pola pemeliharaan ekstensif kurang menguntungkan. Menurut Suprijatna (2010), pola pemeliharaan ayam kampung secara ekstensif kurang optimal dibandingkan pola pemeliharaan intensif. Nataamijaya (2010) menambahkan bahwa ayam lokal yang dipelihara dengan sistem umbaran (ekstensif) hanya menghasilkan 50-60 telur/tahun, sedangkan yang dipelihara secara intensif mampu menghasilkan telur lebih dari 150-200 butir/tahun. Masalah yang banyak dihadapi dalam pengembangan budidaya ayam kampung salah satunya karena masih menggunakan sistem yang ekstensif/tradisional dimana ayam kampung hanya diumbar di area sekitar rumah dan pakan yang berikan tidak sesuai standar sehingga menyebabkan produktivitasnya rendah (Ijah \& Altandjung, 2019).

UKM Putra Budi bergerak di bidang peternakan ayam kampung tradisional yang belum mengetahui pola yang benar dalam memelihara ayam kampung secara intensif sehingga produktivitasnya belum optimal. Upaya untuk meningkatkan produktivitas ayam kampung yang baik dan efisien adalah dengan menerapkan pola pemeliharaan dari pola ekstensif/tradisional menjadi pola pemeliharaan secara intensif. Salah satu solusi yang dapat dilakukan oleh UKM Putra Budi dalam meningkatkan pendapatan yaitu dengan menerapkan pola pemeliharaan ayam kampung intensif. Pemeliharaan ayam kampung secara intensif harus diikuti dengan sistem manajemen pencegahan ataupun pengendalian penyakit (Adnyana et al., 2016). Berdasarkan latar belakang dan permasalahan tersebut, secara umum pengabdian Hibah Pengabdian Research Group (RG) PNPB UNS ini bertujuan untuk 
meningkatkan usaha budidaya ayam kampung UKM Putra Budi milik Bapak Apri dengan menerapkan usaha budidaya yang intensif, diversifikasi pola pemasaran ayam kampung, dan mampu meningkatkan pendapatan dari mitra.

\section{METODE}

Kegiatan pengabdian kepada masyarakat ini bertujuan untuk peningkatan usaha budidaya ayam kampung bertempat di Desa Bekonang, Kecamatan Mojolaban, Kabupaten Sukoharjo. Kegiatan pengabdian ini dilaksanakan oleh Bapak Apri selaku pemilik UKM Putra Budi. Selama 5 tahun, Bapak Apri menggunakan metode pemeliharan yang masih sederhana dan belum dilakukan secara intensif sehingga produktivitasnya rendah. Sebagai upaya untuk mengatasi permasalahan UKM Putra Budi, tim pengabdian memberikan pendampingan melalui 3 tahap. Tahap tersebut yaitu penyuluhan dan bimbingan teknis (Bimtek), tahap pengenalan dan aplikasi kandang ayam kampung secara intensif, dan tahap evaluasi pemeliharaan ayam secara intensif pada peternak tradisional.

\section{Penyuluhan dan Bimbingan Teknis (Bimtek)}

Kegiatan berlangsung selama \pm 3 bulan antara 12 Mei 2020 - 14 Agustus 2020 yang diawali dengan melakukan penyuluhan dan bimbingan teknis terkait pemeliharaan ayam kampung yang intensif dan ramah lingkungan. Penyuluhan dan bimbingan teknis pengelolaan usaha ayam kampung meliputi perbaikan pakan, bibit, kesehatan, sanitasi, dan pemasaran. Kegiatan ini bertujuan untuk meningkatkan pengetahuan peternak tentang pengelolaan usaha ayam kampung yang intensif dan ramah lingkungan.

\section{Tahap Pengenalan dan Aplikasi Kandang Ayam Kampung secara Intensif}

Kandang intensif untuk pola budidaya pemeliharaan ayam kampung pada umumnya memiliki ukuran kandang $10 \mathrm{~m} \times 8 \mathrm{~m}$ dengan kapasitas maksimal 450 ekor ayam kampung. Apabila jumlah ayam kampung yang dipelihara berjumlah 75 ekor, maka luasan kandang yang dibutuhkan adalah ukuran 2,5 $\mathrm{m} \mathrm{x}$ 4,25 m dengan asumsi per meter mampu menampung 7-8 ekor ayam kampung. Jenis kandang dengan ukuran tersebut biasanya berjenis kandang litter/postal dimana lantai yang digunakan sebagai alas berupa sekam padi, jerami padi, serbuk gergaji, dan batu kapur. Tinggi ketebalan alas sekitar 7-9 $\mathrm{cm}$. Untuk alas/litter yang sudah basah dan lembap dapat dilakukan pembalikan atau penambahan alas dengan ukuran total lebih tinggi dari ukuran alas sebelumnya. Dalam proses pembuatan kandang perlu dilakukan sinkronisasi pada aspek teknik pembuatan kandang, bentuk dan bahan yang digunakan, kapasitas daya tampung ayam kampung, suhu dan sanitasi kandang, serta sistem sirkulasi udara dalam kandang yang sesuai dengan standar agar kondisi kandang tetap stabil.

\section{Tahap Evaluasi Pemeliharaan Ayam secara Intensif pada Peternak Tradisonal}

Pada tahap ini dilakukan evaluasi dari seluruh kegiatan yang telah dilaksanakan. Tahap ini bertujuan untuk memantau tingkat keberhasilan dari program pengabdian yang telah dilakukan mulai dari pemeliharaan sampai pada penanganan pascapanen. Evaluasi menggunakan fact sheets yang telah disiapkan oleh tim pengabdian. Fact sheets ini memudahkan peternak memasukkan data yang berupa total kenaikan bobot badan, jumlah konsumsi pakan, suhu dan kelembaban kandang, dan jumlah kematian ayam

\section{HASIL DAN PEMBAHASAN}

\section{Penyuluhan dan Bimbingan Teknis (Bimtek)}

Penyuluhan dan bimbingan teknis bertujuan untuk memberikan pemahaman tentang pemeliharaan ayam kampung yang intensif dan ramah lingkungan. Materi yang disampaikan pada saat penyuluhan dan bimbingan teknis pengelolaan usaha ayam kampung meliputi perbaikan pakan sesuai standar konsumsi harian, pemilihan bibit ayam kampung yang baik dan sehat, pencegahan dan penanganan kesehatan, sanitasi dalam perkandangan, dan pola pemasaran ayam kampung serta cara diversifikasi produk olahan ayam kampung. Pola pemeliharaan ayam kampung secara intensif merupakan suatu sistem dimana ayam kampung dibudidayakan dengan cara dikandangkan selama periode pemeliharaan. Cara pemeliharaan ini sangat membantu dalam peningkatan kenaikan bobot badan harian, efisiensi pakan, dan menurunnya tingkat kematian ternak.

Sistem pemeliharaan yang intensif ini dapat dimodifikasi menjadi sistem semi-intensif mengingat kemampuan dan luasan kandang peternak juga berbeda-beda. Akan tetapi, dari 
segi hasil yang didapatkan masih lebih sedikit daripada pola pemeliharaan intensif. Menurut Iskandar (2010), jumlah pakan yang diberikan harus sesuai dengan kebutuhan nutrien harian yang cukup untuk memenuhi kebutuhan hidup pokok, reproduksi, dan produksi (telur dan daging). Selain pakan, kesehatan juga mempengaruhi kualitas ayam sehingga kebersihan kandang ayam menjadi faktor yang penting agar ayam terhindar dari penyakit (Putra \& Siska, 2019). Mengontrol kesehatan ayam juga dapat menjadi solusi untuk menekan angka kematiannya (Umam et al., 2014). Sanitasi kandang juga perlu dilakukan karena sanitasi kandang dapat mencegah masuknya bibit penyakit yang akan menyerang ternak (Libriani et al., 2020). Selanjutnya, tim pengabdian juga memberikan penyuluhan tentang pemasaran ayam kampung. Pemasaran dapat dilakukan dengan mengolah ayam kampung menjadi ayam ungkep karena olahan ayam kampung lebih diminati masyarakat (Siswanti et al., 2018). Sutriyono and Setianto (2019) menyebutkan bahwa salah satu jalur pemasaran yang dapat dilakukan peternak adalah dengan menjual ternak ke pasar tradisional, rumah makan, dan restoran.

\section{Tahap Pengenalan dan Aplikasi Kandang} Ayam Kampung secara Intensif

Kandang peternak UKM Putra Budi milik Bapak Apri yang berlokasi di Bekonang awalnya berukuran $1.5 \mathrm{~m}$ x $3 \mathrm{~m}$ berdinding seng dengan kapasitas 100 ekor dan berdampingan dengan rumah. Setelah dikenalkan sistem kandang yang baik model kandang yang disarankan berdinding tembok dan beratap asbes ukuran $5 \mathrm{~m} \times 6 \mathrm{~m}$ dengan kapasitas 200 ekor ayam kampung (Gambar 1). Kandang yang baik juga mempunyai ventilasi yang cukup untuk sirkulasi udara dan sinar matahari yang dapat masuk ke dalam kandang. Hal ini karena sistem perkandangan memegang peran yang sangat penting dalam menghasilkan kinerja produksi ternak yang dipelihara. Tingkat kenyamanan ternak juga sangat bergantung dari pola dan tipe/desain kandang yang digunakan. Luas kandang merupakan perkalian antara kebutuhan kandang perekor dengan jumlah ayam yang akan dipelihara. Ketidaksesuaian ukuran kandang dengan kapaitas kandang akan berakibat pada performa ternak yang dipelihara. Kandang yang nyaman membuat aktivitas ternak lebih nyaman sehingga mampu memperbaiki efisiensi penggunaan nutrien bagi ayam. Selain itu, posisi letak kandang harus berjauhan dengan pemukiman sehingga tidak mengganggu lingkungan sekitar akibat dampak penanganan limbah. Kondisi kandang yang ideal untuk densitas kepadatan kandang adalah $8-11 \mathrm{ekor} / \mathrm{m}^{2}$ dengan kondisi temperatur ruangan $32-35,5^{\circ} \mathrm{C}$ dan kelembaban $60-70 \%$. Sistem perkandangan yang baik dapat ditinjau dari baik tidaknya kontruksi kandang dan fungsi kandang serta terpenuhinya persyaratan minimal kandang (Iskandar, 2010). Bahan bangunan kandang yang digunakan harus disesuaikan dengan lama waktu penggunaan kandang. Semakin lama penggunaan kandang maka bahan kandang yang dipilih harus bahan-bahan yang kuat dan kokoh misalnya kayu, besi, baja, dan lain lain. Bahanbahan yang tepat akan membuat kandang menjadi nyaman untuk ternak.

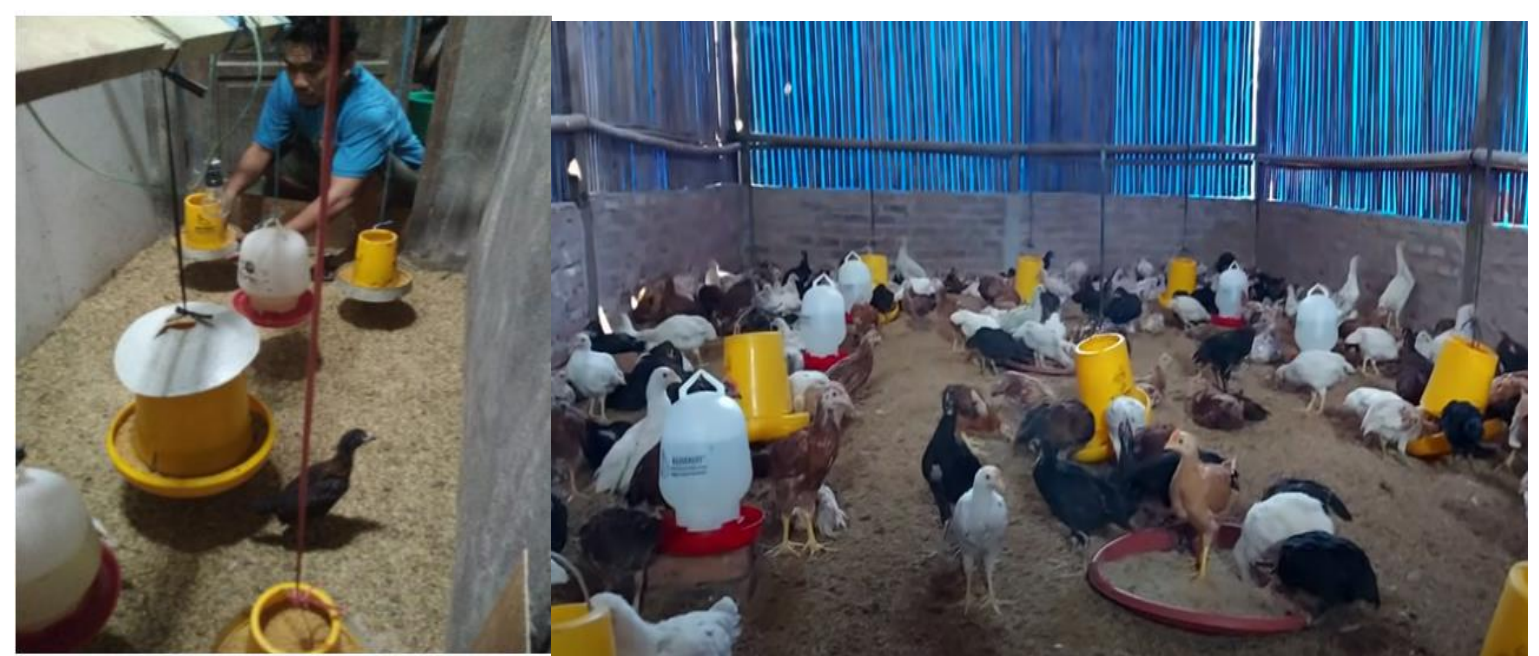

Gambar 1. Kandang pemeliharaan ayam kampung sebelum renovasi (kiri) dan setelah renovasi (kanan) 
Pemilihan bahan kandang mengacu pada masing-masing sifat bahan yang mampu membuat ternak nyaman di dalamnya. Pembuatan tiang dari beton (cor beton) diharapkan dapat menjadikan umur kandang relatif lama. Bahan tiang utama kandang dari beton (cor beton) menjadikan kandang lebih kokoh. Bahan kandang untuk ventilasi menggunakan kayu atau bambu sehingga akan lebih mudah dalam perbaikannya. Atap kandang model monitor dengan ventilasi terbuat dari bingkai kayu dan kawat harmonika, sedangkan lantai kandang terbuat dari semen.

\section{Tahap Evaluasi Pemeliharaan Ayam secara Intensif pada Peternak Tradisional}

Pemeliharaan ayam kampung yang dilakukan di mitra UKM Mitra Budi yaitu dengan melakukan evaluasi kualitasnya dimulai saat anak ayam berumur satu hari (day old chick/DOC). Persiapan brooder box yang dilengkapi dengan bohlam lampu sebagai pemanas dengan suhu $35^{\circ} \mathrm{C}$ dilakukan untuk menampung 100 ekor ayam $/ \mathrm{m}^{2}$. Brooder box dinyalakan 2 jam sebelum DOC dimasukkan. Alat pemanas kandang/brooder berguna untuk menstabilkan dan menjaga suhu maupun kelembaban kandang sehingga sistem metabolisme DOC dapat stabil dan kekebalan meningkat. Air minum yang diberi tambahan antibiotik dan selanjutnya diberi tambahan vitamin diberikan pada hari pertama. Periode starter di dalam brooder berlangsung selama 14 hari. Setelah ayam berumur satu minggu suhu diturunkan menjadi $30^{\circ} \mathrm{C}$. Tingkah laku DOC yang baik dan sehat dapat dilihat dari aktivitas yang gesit dan pergerakan yang aktif. Pemberian pakan periode starter pada minggu pertama diberikan sesering mungkin secara ad libitum. Jenis pakan ayam kampung yang diberikan berbentuk pakan crumble dengan kandungan protein kasar (PK) 21-23\% dan metabolisme energi 3100-3200 kcal. Ayam diturunkan dari kandang brooder ke kandang postal setelah berumur 2 minggu. Sebelumnya kandang postal telah dipersiapkan dengan menutup lantai dengan kapur mati dan sekam. Sekam mempunyai daya serap tinggi dan dapat mempertahankan suhu kandang. Saat ayam diturunkan ke kandang postal pakan, minum, dan tirai kandang dipersiapkan terlebih dahulu.

Pemeliharaan ayam kampung secara intensif harus diikuti dengan pencegahan ataupun pengendalian penyakit (Adnyana et al., 2016). Selain menjaga kebersihan lingkungan peternakan, upaya pengendalian penyakit dapat dilakukan dengan pengobatan dini ketika gejala penyakit mulai tampak serta melakukan vaksinasi (Yosi \& Nurrahmandani, 2020). Hal ini dapat dilakukan secara rutin dengan melakukan program vaksinasi dalam budidaya ternak ayam sehingga penyakit-penyakit yang ditimbulkan oleh virus dan bakteri dapat dihindari. Selain itu, peningkatan produksi dan efisiensi ayam kampung dapat dilakukan dengan perbaikan mutu genetik, nutrien pakan, pola budidaya ternak, pengendalian mortalitas, dan penyakit (Nataamijaya, 2010). Pakan merupakan salah satu faktor yang sangat menentukan keberhasilan suatu usaha budidaya ternak selain dari mutu genetik dan sistem pemeliharaan. Biaya pakan dalam suatu usaha peternakan ayam kampung secara insentif dapat mencapai 60-70\% dari total biaya produksi yang dikeluarkan. Oleh karena itu, usaha budidaya ayam kampung dapat dikatakan berhasil dan menguntungkan apabila ayam kampung dapat tumbuh dan berkembang dengan optimal sesuai target dan mendapatkan keuntungan yang maksimal. Maka dari itu kualitas dan kuantitas pakan yang diberikan harus diperhatikan (Herlina et al., 2015; Kusuma et al., 2016). Bobot badan yang baik dari pola pemeliharaan yang baik dapat dilihat dari kenaikan PBBH (Pertambahan Bobot Badan Harian) ayam kampung pada Tabel 1.

Berdasarkan hasil pengamatan tersebut maka nilai kenaikan ayam kampung pada UKM Putra Budi sudah hampir sesuai dengan standar. Ayam kampung dapat dipanen pada umur 50-60 hari dengan bobot badan $0,7-0,85 \mathrm{~kg}$.

Tabel 1. Rata-rata Konsumsi Pakan dan PBBH Ayam Kampung

\begin{tabular}{ccc}
\hline $\begin{array}{c}\text { Umur } \\
\text { ayam } \\
\text { (minggu) }\end{array}$ & $\begin{array}{c}\text { Konsumsi Pakan } \\
\text { Harian gr/ekor }\end{array}$ & $\begin{array}{c}\text { PBBH } \\
(\mathrm{g})\end{array}$ \\
\hline 1 & 7 & 56 \\
2 & 20 & 105 \\
3 & 33 & 172 \\
4 & 46 & 282 \\
5 & 57 & 353 \\
6 & 66 & 485 \\
7 & 71 & 597 \\
8 & 73 & 672 \\
9 & 74 & 768 \\
10 & 75 & 856 \\
11 & 79 & 974 \\
12 & 85 & 1089 \\
\hline
\end{tabular}

Sumber data: Analisis data primer 2020 
Sedangkan pada umur 12 minggu bobot badan mencapai 1,2-1,3 kg, dengan bobot karkas sebesar 748,67-797,33 g/ekor. Rata-rata bobot karkas adalah 61\% (Arfanda et al., 2019).

UKM Putra Budi sebelum dilakukan pengabdian mengenai jumlah pakan yang diberikan hanya berdasarkan perkiraan dalam pemberian pakannya (1 gayung pakan setara dengan $750 \mathrm{~g}$ pakan). Selain itu juga masih menggunakan pakan seadanya yaitu campuran bekatul, jagung dan konsentrat ayam petelur. Cara tersebut sangat tidak disarankan karena akan mempengaruhi kualitas dan kuantitas pakan sehingga pakan yang diberikan jauh dari standar kebutuhan. Pakan yang diberikan pada ternak selama 24 jam harus memenuhi standar kebutuhan nutrien harian. Kandungan nutrien dalam pakan terdiri dari kandungan kadar air, protein kasar, metabolisme energi, serat kasar, lemak kasar, vitamin, mineral, dan asam amino. Fase pemberian ayam kampung dibagi menjadi 2, yaitu fase starter dan fase finisher. Fase starter dimulai saat ayam berumur 0-2 minggu, dalam fase ini ternak diberi pakan crumble dengan kandungan protein kasar $21-23 \%$ dan metabolisme energi 3100-3200 kcal dengan jumlah kuantitas yang diberikan bertambah setiap minggu. Pada fase ini terjadi peningkatan kenaikan bobot badan harian yang cukup signifikan. Fase finisher dimulai dari ayam umur 2-12 minggu. Pada fase ini ayam kampung mendapatkan pakan dengan kandungan protein kasar 18-19\% dan metabolisme energi sebesar 2700-2800 kcal untuk memenuhi kebutuhan harian ayam kampung. Pertumbuhan ayam kampung akan meningkat cepat pada fase starter kemudian melambat kemudian bertambah lebih cepat hingga umur 7 minggu dan terjadi perlambatan kenaikan PBBH sampai umur 10 minggu (Gambar 2). Jumlah angka deplesi pada ayam kampung tersebut sebesar $\pm 5 \%$, hal ini dapat disebabkan oleh beberapa faktor khususnya pada pola manajemen perkandangan dan pemeliharaan yang baik.

Setelah pemeliharaan selama 3 bulan, ayam kampung yang dibesarkan sudah mencapai bobot 800-1.000 gr. Ayam kampung tersebut dijual dalam keadaan hidup maupun sudah diolah. UKM Putra Budi mengolah daging ayam kampung menjadi ayam ungkep (Gambar 3). Pemasar hasil produk kegiatan ini adalah pedagang ayam, UKM olahan daging ayam kampung, rumah makan, dan restoran.

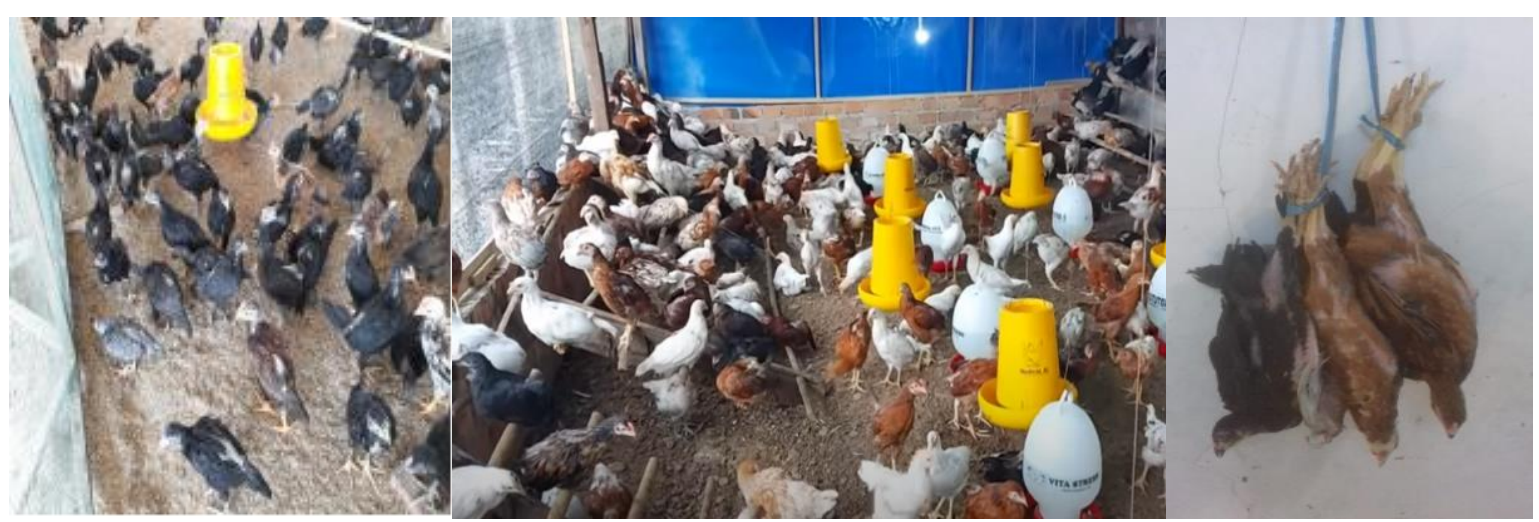

Gambar 2. Pembesaran ayam kampung

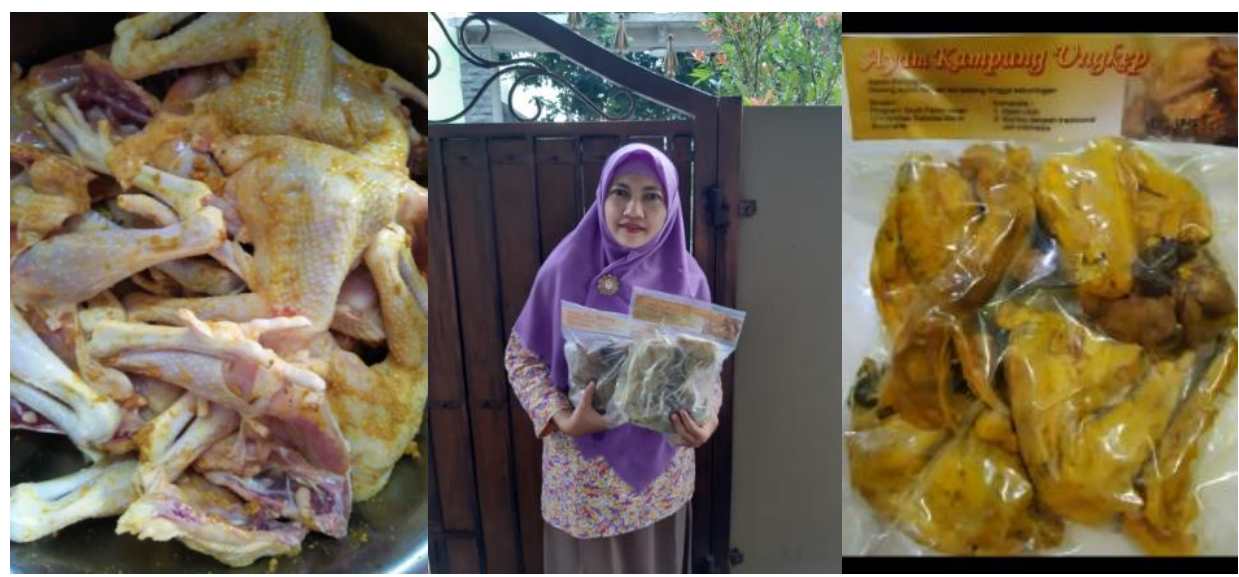

Gambar 3. Produk ayam kampung setelah diolah menjadi ayam ungkep

Copyright (C) 2021 PRIMA: Journal of Community Empowering and Services 
Tabel 2. Analisis Biaya dan Penerimaan Budidaya Ayam Kampung Intensif

\begin{tabular}{clccc}
\hline No & \multicolumn{1}{c}{ Uraian } & Fisik & Harga Satuan & Jumlah $(\mathrm{Rp})$ \\
\hline 1 & Hasil penjualan ayam(kg) & 190 & 40.000 & 7.600 .000 \\
& & & Total & 7.600 .000 \\
\hline 1 & DOC (ekor) & 200 & 5000 & 1.000 .000 \\
2 & Pakan (kg) & 500 & 7000 & 3.500 .000 \\
3 & Obat-obatan (L) & 1 paket & & 100.000 \\
4 & Listrik & 3 bulan & 100000 & 300.000 \\
5 & Tenaga kerja & 3 bulan & 400000 & 1.200 .000 \\
6 & Depresiasi peralatan & & Total & 6.200 .000 \\
& & & \\
\hline & Keuntungan 1 periode/200 ekor & & 1.400 .000 \\
\hline
\end{tabular}

Pasar potensial ini berada di Kota Solo dan daerah sekitarnya. Pedagang ayam kampung banyak ditemui di Pasar Silir (Pasar ayam di Kota Solo). Analisis biaya dan penerimaan budidaya ayam kampung intensif tersaji pada Tabel 2.

Berdasarkan analisis ekonomi, pemeliharaan ayam kampung peternak Bapak Apri dengan 200 ekor ayam mengalami deplesi $5 \%$ dan memberikan keuntungan sebesar Rp1.400.000,00 per periode pemeliharaan. Kegiatan pengabdian yang dilakukan komponen biaya pakan memiliki proporsi biaya terbesar yaitu Rp3.500.000,00. Hal ini sejalan dengan penelitian Suprayogi et al. (2018) yang menunjukkan bahwa dalam pemeliharaan secara intensif, pakan mempunyai proporsi biaya terbesar. Berdasarkan analisis ekonomi, pemeliharaan penggemukan ayam kampung mampu menghasilkan $\mathrm{R} / \mathrm{C}$ rasio sebesar 1,12 sehingga nilai tersebut dapat dikatakan bahwa usaha peternakan ayam kampung yang dilakukan UKM Putra Budi ini layak untuk dikembangkan. R/C (Revenue Cost Ratio) merupakan nilai perbandingan antara total penerimaan dengan total biaya. Jika R/C Ratio > 1, maka usaha yang dijalankan mengalami keuntungan atau layak untuk dikembangkan. Jika R/C Ratio < 1, maka usaha tersebut mengalami kerugian atau tidak layak untuk dikembangkan. Selanjutnya jika R/C Ratio $=1$, maka usaha berada pada titik impas (Break Event Point) (Asnidar \& Asrida, 2017).

\section{KESIMPULAN}

Manajemen pola pemeliharaan ayam kampung yang dilakukan secara intensif memberikan hasil yang sesuai dengan target yang diinginkan. Hal ini dapat dilihat dari pertumbuhan ayam kampung yang lebih tinggi dengan masa pemeliharaan yang lebih singkat
(10-12 minggu), dan tingkat kematian yang rendah $(5 \%)$. Pemeliharaan ayam secara intensif sebanyak 200 ekor mengalami deplesi 5\% dan memberikan keuntungan sebesar Rp1.400.000,00 per periode pemeliharaan.

\section{UCAPAN TERIMA KASIH}

Penulis menyampaikan rasa terima kasih kepada Universitas Sebelas Maret melalui Hibah Research Group Pengabdian dengan dana PNBP tahun Anggaran 2020 yang tercantum pada surat perjanjian Nomor: 453/UN27.21/PN/2020.

\section{DAFTAR PUSTAKA}

Adnyana, I. P. G. G., Mahardika, I. G., \& Sukanata, I. W. (2016). Pengaruh lama penyimpanan terhadap kualitas telur ayam kampung dari kelompok peternak ayam buras mertasari di Kecamatan Abiansemal Kabupaten Badung. Jurnal Peternakan Tropika, 4(3), 506-518. https://ojs.unud.ac.id/index.php/tropika/arti cle/view/27286

Arfanda, A. I., Suprijatna, E., \& Isroli. (2019). Pengaruh frekuensi dan periode pemberian pakan terhadap bobot relatif organ limfoid ayam buras super. Jurnal Sain Peternakan Indonesia, 14(3), 306-311. https://doi.org/10.31186/jspi.id.14.3.306311

Asnidar, \& Asrida. (2017). Analisis kelayakan usaha home industry kerupuk opak di Desa Paloh Meunasah Dayah Kecamatan Muara Satu Kabupaten Aceh Utara. Jurnal Sains Pertanian, 1(1), 39-47.

BPS. (2020). Rata-rata konsumsi per kapita seminggu beberapa macam bahan makanan penting.

https://www.bps.go.id/statictable/2014/09/ 08/950/rata-rata-konsumsi-per-kapita- 
seminggu-beberapa-macam-bahanmakanan-penting-2007-2021.html

Dewi, N. L. P., Utama, M. S., \& Yuliarmi, N. N. (2017). Faktor-faktor yang mempengaruhi produktivitas usaha tani dan keberhasilan program simantri di Kabupaten Klungkung. Jurnal Ekonomi dan Bisnis Universitas Udayana, 6(2), 701-728. https://ojs.unud.ac.id/index.php/EEB/articl e/view/24578

Herlina, B., Novita, R., \& Karyono, T. (2015). Pengaruh jenis dan waktu pemberian ransum terhadap performans pertumbuhan dan produksi ayam broiler. Jurnal Sain Peternakan Indonesia, 10(2), 107-113. https://doi.org/10.31186/jspi.id.10.2.107113

Ijah, H., \& Altandjung, R. I. (2019). Determinasi peluang adopsi teknologi budidaya ternak ayam KUB di Papua Barat. Jurnal Pengkajian dan Pengembangan Teknologi Pertanian, 22(2), 201-212. https://doi.org/10.21082/jpptp.v22n2.2019. p215-226

Iskandar, S. (2010). Seri peningkatan manfaat sumberdaya genetik ternak usahatani ayam kampung.

70.

http://balitnak.litbang.pertanian.go.id/phoc adownload/panduan/panduan\%20teknis\%2 0ternak\%20ayam\%20kampung. doc

Kusuma, H. A., Mukhtar, A., \& Dewanti, R. (2016). Pengaruh tingkat pembatasan pemberian pakan (Restricted feeding) terhadap performan ayam broiler jantan. Sains Peternakan, 14(1), 43-51. https://doi.org/10.20961/sainspet.v14i1.87 78

Libriani, R., Nafiu, L. O., Saili, T., Abadi, M., Sulfitrana, A., Salido, W. L., \& Isnaeni, P. (2020). Pencegahan penyakit pada ternak ayam kampung melalui bimbingan teknis manajemen sanitasi dan biosecurity di Kecamatan Abeli. Jurnal Pengabdian Masyarakat Ilmu Terapan, 2(2), 111-116. http://ojs.uho.ac.id/index.php/JPMIT/articl e/view/14071

Muhtar, Nasrullah, \& Surya, B. (2020). Pemberdayaan wirausaha ternak dalam peningkatan pendapatan masyarakat Kecamatan Libureng Kabupaten Bone. Seminar Nasional Penelitian \& Pengabdian Kepada Masyarakat 2020, Makassar, Indonesia.

http://jurnal.poliupg.ac.id/index.php/snp2m /article/view/2566
Munir, I. M., Haryani, D., Amin, N., Kardiyanto, E., Muchtami, A., Makmur, A., \& Kusumawati, S. (2016). Kajian pengembangan ayam kampung unggul badan litbang pertanian (KUB) di Provinsi Banten 2016.

Nangoy, F. J., \& Karisoh, L. C. H. (2018). Pemberdayaan masyarakat pedesaan pada ayam kampung pasawungen di Desa Pahaleten Kecamatan Kakas Kabupaten Minahasa Provinsi Sulawesi Utara. Jurnal LPPM Bidang Sains dan Teknologi, 5(2), 57-66.

https://ejournal.unsrat.ac.id/index.php/lpp msains/article/view/24091

Nataamijaya, A. G. (2010). Pengembangan potensi ayam lokal untuk menunjang peningkatan kesejahteraan petani. Jurnal Penelitian dan Pengembangan Pertanian, 29(4), 131-138. http://ejurnal.litbang.pertanian.go.id/index. php/jppp/article/view/7759

Peraturan pemerintah (Perpres) No. 44. (2016). Peraturan Presiden Republik Indonesia nomor 44 tahun 2016 tentang daftar bidang usaha yang tertutup dan bidang usaha yang terbuka dengan persyaratan di bidang penanaman modal.

Permana, S. H. (2017). Strategi peningkatan usaha mikro, kecil, dan menengah (UMKM) di Indonesia. Aspirasi: Jurnal Masalah-Masalah Sosial, 8(1), 93-103. https://jurnal.dpr.go.id/index.php/aspirasi/a rticle/view/1257

Pratitis, W., Wida, E., \& Dwi, S. (2018). Menumbuhkan wirausaha melalui program IBIKK budidaya ayam kampung di experimental farm Jatikuwung Universitas Sebelas Maret. Jurnal DIANMAS, 7(1), 2734.

http://jurnaldianmas.org/index.php/Dianma s/article/view/108

Putra, O. A., \& Siska, I. (2019). Aspek teknis pemeliharaan ayam kampung di Kecamatan Kuantan Mudik Kabupaten Kuantan Singingi. Journal of Animal Center, 1(2), 139-160.

http://ejournal.uniks.ac.id/index.php/JAC/a rticle/view/380

Siswanti, Anandito, R. B., \& Affandi, D. R. (2018). Ibm industri rumah tangga ayam ungkep di Gembongan, Kecamatan Kartasura, Kabupaten Sukoharjo. Prima, Journal of Community Empowering and 
Services,

2(1),

$15-20$. https://doi.org/10.20961/prima.v2i1.36113

Suprayogi, W. P. S., Wida, E., \& Dwi, S. (2018). Budidaya ayam kampung intensif melalui program pengembangan usaha inovasi kampus. Inoteks, 22(1), 18-27. https://journal.uny.ac.id/index.php/inotek/a rticle/view/18917

Suprijatna, E. (2010). Strategi pengembangan ayam lokal berbasis sumber daya lokal dan berwawasan lingkungan. Seminar Nasional Unggas Lokal ke IV, Semarang, Indonesia.

Suresti, A., \& Wati, R. (2012). Strategi pengembangan usaha peternakan sapi potong di Kabupaten Pesisir Selatan. Jurnal Peternakan Indonesia, 14, 249-262. https://doi.org/10.25077/jpi.14.1.249262.2012

Sutriyono, \& Setianto, J. (2019). Pendapatan pedagang ayam kampung pada pasar tradisional di Kota Bengkulu. Jurnal Sain Peternakan Indonesia, 14(4), 440-447. https://doi.org/10.31186/jspi.id.14.4.440447
Tarigan, I. S., Gea, I., Situmorang, M., Dubois, W. R., \& Widiastuti, M. (2021). Percepatan produksi daging ayam kampung melalui pengontrolan aspek pemeliharaan: Upaya peningkatan ekonomi keluarga pra sejahtera. Jurnal Pionir, 7(1), 10-26. http://jurnal.una.ac.id/index.php/pionir/arti cle/view/1869

Umam, M. K., Prayogi, H. S., \& Nurgiartiningsih, V. M. A. (2014). Penampilan produksi ayam pedaging yang dipelihara pada sistem lantai kandang panggung dan kandang bertingkat. Jurnal Ilти-Ilmu Peternakan, 24(3), 79-87. https://jiip.ub.ac.id/index.php/jiip/article/vi ew/207

Yosi, F., \& Nurrahmandani, M. (2020). Manajemen kesehatan dan pengendalian penyakit ayam broiler di peternakan din dahlan Desa Seri Kembang III Kecamatan Paraman Kabupaten Ogan Ilir. Jurnal Peternakan, 4(1), 68-74. http://jurnal.umtapsel.ac.id/index.php/peternakan/article/vi ew/1414 